\title{
CALL IMITATION AND CALL MODIFICATION IN RED CROSSBILLS
}

\author{
Patrick C. Keenan and Craig W. Benkman ${ }^{1}$ \\ Department of Zoology and Physiology, University of Wyoming, Laramie, WY 82071
}

\begin{abstract}
Open-ended learning of flight calls has been found consistently in the subfamily Carduelinae. Understanding call learning is especially important in Red Crossbills (Loxia curvirostra complex) because calls appear to play an instrumental role in assortative mating, perhaps by acting as a marker trait that signals ecological adaptation for foraging on a particular species of conifer. We analyzed flight call recordings from a banded population of the South Hills (call type 9) crossbill to examine whether young birds imitate the calls of their parents and whether, as adults, individuals modify their calls to match those of their mates. The calls of offspring were more similar to the calls of their parents than to the average adult in the population. This indicates that calls are, at least initially, culturally inherited from parents and thereby could act as marker traits. Adults did later modify their calls to match the calls of their mates, which presumably aids in individual and pair recognition. Comparisons within individuals over time also showed that call structure decreased in similarity to the calls of crossbills with another type of call (type 2) that regularly occur in the South Hills of Idaho. This should make it easier for individuals to distinguish between individuals of different call types. However, one of 91 crossbills recorded over more than one year changed the type of its call. This type 2 female bred successfully with a type 9 male for two years and by the second year changed her call to match that of her type 9 mate.
\end{abstract}

Key words: call learning, call matching, call types, Idaho, Loxia curvirostra, marker trait.

\section{Imitación y Modificación del Reclamo en Loxia curvirostra}

Resumen. El aprendizaje abierto de los reclamos en vuelo ha sido habitualmente observado en la familia Carduelinae. Comprender el proceso de aprendizaje de los reclamos en el complejo Loxia curvirostra es especialmente importante porque los reclamos parecen jugar un papel fundamental en el apareamiento asociativo, quizás porque actúa como un rasgo marcador que indica una adaptación ecológica para alimentarse de una especie particular de conífera. Analizamos las grabaciones de los reclamos en vuelo en una población marcada de Loxia curvirostra de South Hills (tipo vocal 9) para examinar si las aves jóvenes imitan los reclamos de sus progenitores y si, ya como adultos, los individuos modifican sus reclamos para asemejarse a los reclamos de sus parejas. Los reclamos de los hijos fueron más parecidos a los reclamos de sus progenitores que a los de un adulto promedio de la población. Esto indica que los reclamos son, al menos inicialmente, heredados culturalmente de los progenitores, y por esta razón podrían actuar como rasgos marcadores. Los adultos modificaron posteriormente sus reclamos para asemejarse a los reclamos de sus parejas, lo cual probablemente favorece el reconocimiento individual y de pareja. Las comparaciones de individuos en el tiempo también mostraron que la estructura del reclamo redujo su semejanza respecto a los reclamos de individuos de Loxia curvirostra con otro tipo vocal (tipo 2) que aparece de forma regular en South Hills de Idaho. Esto haría más sencillo que los individuos distinguieran entre individuos de diferentes tipos vocales. Sin embargo, uno de los 91 Loxia curvirostra grabados durante más de un año cambió el tipo de su reclamo. Esta hembra de tipo 2 se reprodujo de forma exitosa con un macho de tipo 9 durante dos años, y en el segundo año cambió su reclamo para asemejarse al de su pareja de tipo 9.

\section{INTRODUCTION}

Vocalizations are critical for communication in birds, influencing social interactions, mate choice and reproductive isolation (Mundinger 1970, Kroodsma and Byers 1991, Slabbekoorn and Smith 2002). Most of the research on avian vocalizations has addressed songs, which are typically used only immediately prior to and during the breeding season (Marler 2004). Song, which is generally a male trait, functions to repel other males, attract potential mates, and aid in mate recognition
(Falls 1982, Catchpole and Slater 1995, Marler 2004). Few investigators have examined the role of calls (Manabe and Dooling 1997, Marler 2004, Farnsworth 2005) with the exception of alarm calls (Templeton et al. 2005). Flight calls or contact calls (hereafter calls) are simple sounds that are produced by both male and female birds throughout the year (Nottebohm 1984, Marler 2005). Consequently, calls provide a year-round signal that, among birds in groups, helps coordinate the activities of members (Marler 2004) and has been proposed to aid in the recognition of individuals (Mundinger 1970), flock

Manuscript received 7 June 2007; accepted 12 December 2007.

${ }^{1}$ E-mail: cbenkman@uwyo.edu

The Condor, Vol. 110, Issue 1, pages 93-101. ISSN 0010-5422, electronic ISSN 1938-5422. (c) 2008 by The Cooper Ornithological Society. All rights reserved. Please direct all requests for permission to photocopy or reproduce article content through the University of California Press's Rights and Permissions website, http://www.ucpressjournals.com/reprintInfo.asp. DOI: $10.1525 /$ cond.2008.110.1.93. 
members (Mammen and Nowicki 1981, Farabaugh et al. 1994), and species (Mundinger 1970).

Most studies of calls have focused on cardueline finches (Carduelinae) and parrots (Psittacidae), two groups in which calls are learned (Mundinger 1970, 1979, Nottebohm 1984, Brittanny-Powell et al. 1997). Calls are of interest in these taxa for at least two reasons. First, some cardueline finches and parrots exhibit geographic variation in their flight calls. For example, geographic dialects have been described for Pine Grosbeaks (Pinicola enucleator; Adkisson 1981) and Evening Grosbeaks (Coccothraustes vespertinus; Sewall et al. 2004). Moreover, these dialects in Pine and presumably Evening Grosbeaks correspond to geographic differences in plumage coloration and bill structure that likely reflect genetic differences between dialects (Adkisson 1981, Sewall et al. 2004). Similarly, regional dialects in contact calls have been found in Yellow-naped Amazons (Amazona auropalliata; Wright 1996). However, there is no evidence of corresponding genetic structure in these parrots, suggesting that vocal imitation and movement of individuals between populations limit genetic divergence (Wright and Wilkinson 2001).

Second, open-ended learning of calls has been described for several species of psittacids including Yellow-naped Amazons (Wright 1996) and Budgerigars (Melopsittacus undulates; Farabaugh et al. 1994). Likewise, examples of carduelines beyond their first year of age shifting call structures to match those of their mates (call matching) indicates that they are also open-ended learners with regard to their calls (Mundinger 1979, Nottebohm 1984). For example, all six cardueline species in four genera studied in captivity by Mundinger (1979) exhibited pair matching of calls, and three species, when paired with heterospecifics, imitated the calls of their mates. One species of cardueline finch, the Pine Siskin (Carduelis pinus), also imitates the calls of flock mates. This suggests that call learning in carduelines may relate not only to pair bonding but may play a role in the recognition of flock mates and group identity (Mundinger 1979).

Here we seek to determine whether, in the wild, Red Crossbills (Loxia curvirostra complex), a species complex of cardueline finches, imitate the calls of their parents, and the extent to which individuals modify their calls over time. Young Red Crossbills are known to imitate the calls of foster parents in aviaries, but captive adult crossbills have not been found to modify their calls over time (Groth 1993a). Whether adult crossbills modify their calls in the wild to match those of their mates (Groth 1993b) is unknown and, other than studies documenting call matching in pairs, we are unaware of studies of call learning in cardueline finches in the wild.

Calls of Red Crossbills do not relate to geographic distribution, but instead distinguish birds with particular types of calls (hereafter call types) that differ in bill and body size but not in plumage coloration (Groth 1993a, Benkman 1993, 1999). Nine call types are recognized in North America (Groth 1993a, Benkman 1999), with each adapted for feeding on seeds in the cones of specific species of conifers (Benkman 1993, 1999, Parchman and Benkman 2002). Nearly all call types exhibit nomadism in search of abundant conifer cone crops and therefore often encounter other call types when breeding (e.g., during field studies from May to August in 2004-2006 in the South Hills, Idaho, five call types were captured in mist nets).

Understanding call learning is especially important in crossbills because calls appear to play an instrumental role in assortative mating, perhaps by acting as a marker trait that signals ecological adaptation for foraging on a particular species of conifer (Smith et al. 1999, Snowberg and Benkman 2007). Marker traits are behavioral or morphological characters that signal group identity and can become linked to a trait that is under divergent selection. Importantly, under such circumstances, theory indicates that a marker trait in conjunction with female preference for it may result in speciation (Dieckmann and Doebeli 1999, Irwin and Price 1999). Indeed, female Red Crossbills preferentially pair with males of the same call type in both aviaries (Snowberg and Benkman 2007) and the wild (Smith and Benkman 2007). For example, only six of $820(<1 \%)$ breeding South Hills crossbills (call type 9) in 2001 and 2002 paired heterotypically because of the combined effects of assortative mating and the low frequency of other call types (Smith and Benkman 2007). Because young crossbills learn their calls (Groth 1993a), knowing whether crossbills learn their calls from their parents rather than from other individuals in the population, whether crossbills are open-ended learners that modify their calls over time, and the extent to which such modification occurs is important for understanding the role of calls in the ecology and evolution of crossbills.

If calls and hence preferences to mate are learned from parents, then assortative mating by call type (Smith and Benkman 2007, Snowberg and Benkman 2007) will lead to a reduction in gene flow facilitating divergence among call types. For example, young Darwin's finches (Geospiza spp.) imprint on the songs of their parents, allowing for the divergence of lineages that produce different song types (Grant and Grant 1996). This scenario involves the cultural transmission of song characteristics from male parents to male offspring and imprinting of female offspring leading to their selection of mates that have songs that are recognizable as conspecific (Grant and Grant 1996). Hybridization, therefore, is most likely to occur when there are errors in learning and imprinting (Grant and Grant 1996). On the other hand, if individuals learn from unrelated individuals and especially change their call structure to the extent that they would be recognized as a different call type, then we do not expect different call types to diverge genetically, as found in Yellow-naped Amazons (Wright and Wilkinson 2001). In addition, such shifts in call structure would cause us to overestimate the extent of assortative mating by call type. 


\section{METHODS}

Our research focused on South Hills crossbills, which are resident and common in the South Hills of Idaho (Benkman 1999, Benkman et al. 2001, 2003, 2005). South Hills crossbills commonly co-occur during the breeding season with two other less common nomadic crossbill call types, types 2 and 5 (Smith and Benkman 2007).

\section{FIELD EFFORTS}

We captured Red Crossbills using mist nets from late May through mid-August and for one week in September in 20042006 (a total of 1329 captures of crossbills during 210 days netting) where crossbills have been captured and banded since 1997. Most of our fieldwork was conducted in the general vicinity of Porcupine Springs $\left(42.2^{\circ} \mathrm{N}, 114.3^{\circ} \mathrm{W}\right)$. Each crossbill was banded with an anodized U.S. Fish and Wildlife Service aluminum band, and adults were banded with a unique combination of plastic color bands; adults exhibiting symptoms of scaly leg mites (Knemidokoptes jamaicensis) were banded with only plastic color bands (Benkman et al. 2005). In 2006, immature crossbills were uniquely color-banded when at least one parent was known. After birds were banded, sexed, aged, and measured, they were either released immediately or placed in a dark holding box for several minutes before release. Some juvenile crossbills were released without being measured. We used a ME-66 directional microphone (Sennheiser Electronic Corporation, Old Lyme, Connecticut) and a PMD222 cassette recorder (Marantz America, Inc., Aurora, Illinois) to record calls of crossbills upon release. Red Crossbill calls, like those of other carduelines, are short, frequency-modulated sweeps that, within an individual, range in frequency from 2-6 kHz and are approximately $50 \mathrm{msec}$ in length (Groth 1993a). Crossbills make a variety of other calls (e.g., alarm calls, excitement calls; Groth 1993a) that are made much less frequently and are not considered here.

We determined the pairing status and parent-offspring relationships of banded crossbills during the breeding season based on observations in the netting area, and during point count surveys (L. Santisteban, New Mexico State University, unpubl. data) and resighting efforts (Smith and Benkman 2007). Our analyses included only crossbill pairs for which we observed the male guarding the female, the female begging from the male, copulation, contact chipping and synchronized movements, or affiliation during nest construction or while foraging for periods of 10-20 minutes. We determined family groups and parent-offspring relationships by observations of juveniles that begged from and were fed by adults, as well as observations of males and females moving together with dependent young. Often, birds recognized as potential pairs on arrival to the netting area were in vocal contact with each other and convened following capture and release. However, because immature crossbills that are dependent on their parents usually do not give adult-like calls, they generally required recapture at a later date to determine if their calls matched those of their parents. Because of the difficulty of recapturing these immature crossbills, we identified only 17 first-year crossbills that gave adult-like calls for which we had a recording from at least one parent. We assumed that the social parent was also the genetic parent because several lines of evidence, including mate guarding by males, the large amount of food males provide to their mates and offspring, the relatively small testis size of males (Smith and Benkman 2007 and references therein), and no evidence of extra-pair paternity in 34 broods of Red Crossbills in Norway (Kleven et al. 2008) indicate that extra-pair paternity is rare in Red Crossbills.

We determined whether young crossbills gave adult-type calls or postfledging "chit-too" begging calls (Groth 1993a) by visually inspecting spectrograms. We included only South Hills crossbills in our analyses and differentiated them from the other call types as in previous studies (Smith and Benkman 2007). South Hills crossbills are readily distinguished from types 2 and 5 by the presence of an initial component of their call that increases in frequency (Smith and Benkman 2007).

\section{STATISTICAL ANALYSES}

We used the cross-correlation method in Canary 1.24 (Cornell Lab of Ornithology, Ithaca, New York) to estimate call similarity. The cross-correlation method slides two spectrograms past each other, compares their overall similarity with respect to frequency and time, and outputs normalized values of similarity with values from zero to one (Charif et al. 1995). A similarity value of zero represents no overlap, whereas a value of one represents complete overlap. To create spectrograms, we first input crossbill recordings into Raven 1.2 (Cornell Lab of Ornithology, Ithaca, New York). The sampling rate was set to $44.1 \mathrm{kHz}$ and the sample size option set to 16 bits. Then we produced spectrograms using the following settings: $533.2 \mathrm{~Hz}$ filter bandwidth, 512 points frame length, grid resolution $0.36 \mathrm{msec}$, $86.1 \mathrm{~Hz}, 93 \%$ overlap, Fast Fourier transform size 512 points, Blackman window and $-76 \mathrm{~dB}$ clipping level. In some cases, we adjusted the clipping level from between $-66 \mathrm{~dB}$ to $-86 \mathrm{~dB}$ when producing a spectrogram to compensate for extraneous background noise (Charif et al. 1995). Sound files were then converted to Canary 1.24 sound files using FileInfo 1.3 (Shopsin 2002-2004). Cross-correlation values are presented parenthetically \pm SE where appropriate. In all cases, assumptions of normality and homogeneity of variance were met.

To determine if immature crossbills imitate the calls of their parents, we compared the cross-correlation values between 17 immature birds and either their female or male parents to the mean cross-correlation values between these same immature birds and either 22 adult female or 32 adult male South Hills crossbills, respectively, that were not their parents. This is somewhat analogous to measuring heritability, which 
is the quantitative extent to which offspring resemble their parents relative to the population mean (Ridley 1996). We analyzed the similarity to male and female parents separately because in most cases, only one parent had been recorded. We numbered all the calls in a recording and then randomly selected one exemplar from each individual for all analyses unless noted otherwise.

We conducted three sets of analyses to determine if and how crossbills matched the calls of their mates. First, we compared the cross-correlation values of the calls of mated crossbills to the similarity of calls between all other pairs that we could generate using the calls from 55 females and 79 males (4345 total pairings). Although this comparison enabled us to determine if mated pairs tended to match their calls, it may not have allowed us to differentiate between call modification and preferential pairing of females with males having the most similar call structures to their own. Second, we compared the cross-correlation values of observed pairs to those of pairs in which each of 25 females was assigned to the male with the most similar call out of a set of 10 males that we selected at random out of the above 79 males. This allowed us to evaluate the extent to which mate choice alone could account for the similarity of calls within actual pairs. If the similarity of calls between actual pairs exceeded those in which females were paired with the male having the most similar call, then this would suggest that call matching is at least in part the result of call modification. We limited to 10 males the pool from which females selected because of the costs of searching for mates and delaying mate choice (e.g., delay in pairing and nesting), and the decrease in choices as males become paired. Third, we examined the flight calls of individuals that were observed with a mate during at least one year and were recorded during more than one year. This could provide direct evidence of crossbills modifying their calls to match those of their mates, but is limited by the difficulty of acquiring recordings of individual crossbills with known mates over time.

To provide an overall measure of change in calls over time within individuals, we examined call similarity in crossbills that were recorded on multiple occasions. First, we used linear regression to determine if cross-correlation values decreased as the time interval between recordings increased. Individuals were included only once in this analysis to avoid pseudoreplication, and we gave preference to calls that were recorded at the most distant time intervals in order to maximize the probability of detecting shifts in call structure. We analyzed females and males separately to determine if the sexes differed in their tendency to vary call structure over time. Second, we also grouped this same set of flight calls produced by individual birds as: 1) within a single recording, 2) within a year (breeding season; 3-106 days), 3) one year (315-485 days) between recordings, 4) two years (652-856 days) between recordings, or 5) more than two years (1045-1828 days) between recordings. We determined the cross-correlation values for these different time intervals, and we tested whether calls made by individuals within a season were more similar than those made between seasons with one-tailed $t$-tests.

Finally, we tested whether the calls of individuals recorded more than once became less similar to the calls of type 2 crossbills. In the South Hills, type 2 crossbills are the most common call type other than South Hills crossbills and are found there in at least small numbers every year (Smith and Benkman 2007, PCK, pers. obs.). Given that it is advantageous for South Hills crossbills to preferentially associate and pair with other South Hills crossbills (Smith et al. 1999, Snowberg and Benkman 2007), selection should favor individuals that produce calls that are distinct from other co-occurring call types. We tested whether the calls of South Hills crossbills became less similar to type 2 calls over time by comparing two calls made by each of 114 South Hills crossbills (one call from the first and one from the last recording made of each individual) to one of 19 type 2 calls (randomly selected with replacement) using a one-tailed paired $t$-test.

\section{RESULTS}

\section{CALL LEARNING BY IMMATURE CROSSBILLS}

The calls of first-year crossbills were more similar to those of their female parents (cross-correlation value: $0.73 \pm 0.04, n=11$ ) or to their male parents (cross-correlation value: $0.73 \pm 0.02, n=11)$ than they were to the calls of other females (cross-correlation value: $0.66 \pm 0.02, n=10$; $t_{9}=2.5, P=0.02$ ) or of other males (cross-correlation value: $\left.0.70 \pm 0.02, n=11 ; t_{10}=2.8, P=0.009\right)$, respectively. Examples of the calls of both parents and one offspring are shown in Figure 1.

\section{CALL SIMILARITY OF MATES}

The calls of 25 crossbill pairs were more similar (crosscorrelation value: $0.79 \pm 0.02$ ) than the calls of 4345 possible male-female pairs (cross-correlation value: $0.70 \pm 0.002$; $t_{4367}=5.6, P<0.001$; Fig. 2A). Although call similarity (cross-correlation values) for actual pairs ranged across much of the span of values for all possible pairs (Fig. 2A), many cross-correlation values for actual pairs were clustered above nearly all values for the potential pairs (Fig. 2A). On the other hand, the mean cross-correlation values for actual pairs did not differ from that of the cross-correlation values for simulated pairs when females selected mates with calls that were most similar to their own $\left(t_{48}=-0.6, P=0.53\right.$; Fig. $\left.2 \mathrm{~B}\right)$. However, the variance in cross-correlation values for the actual pairs was greater than that when females selected mates with calls that were most similar to their own (Levene test: $F_{1,48}=8.4$, $P=0.006$ ). Some actual pairs had cross-correlation values that were smaller than expected if females selected more similar mates, whereas more actual pairs had higher cross-correlation 


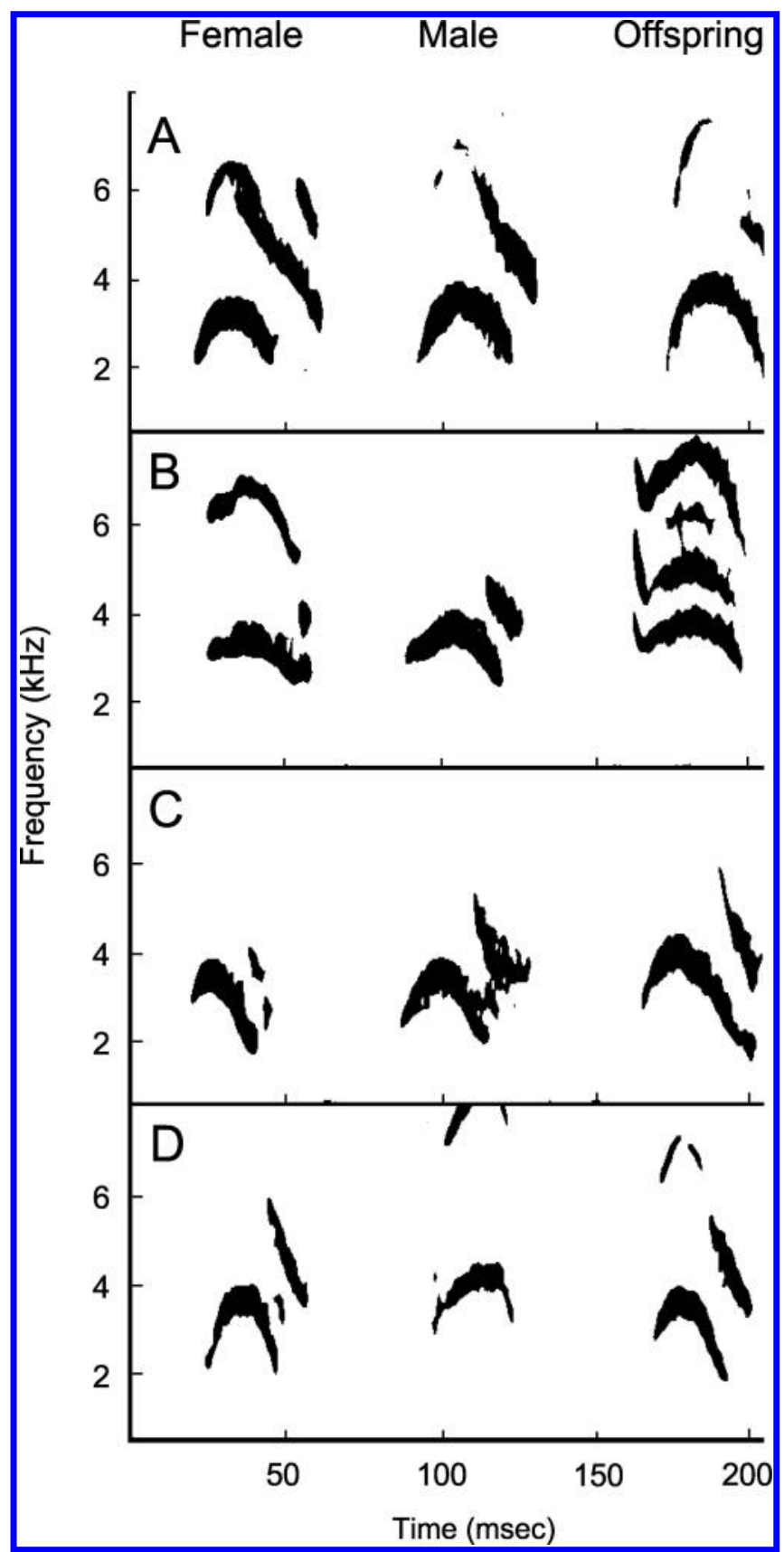

FIGURE 1. Calls produced by four family groups (A-D) of Red Crossbills with type 9 calls in the South Hills, Idaho in 2004-2006. The calls, from left to right, are by adult female, adult male, and offspring.

values than expected (Fig. 2B). These results suggest that some pairs, at least initially, do not match their calls, and that individuals shift their calls to match those of their mates. Examples of call matching are shown in Figure 3.

Our direct observations indicate that individuals changed their calls in order to match those of their mates (Figs. 4 and 5). A particularly striking example was female 80888 (Fig. 4). She

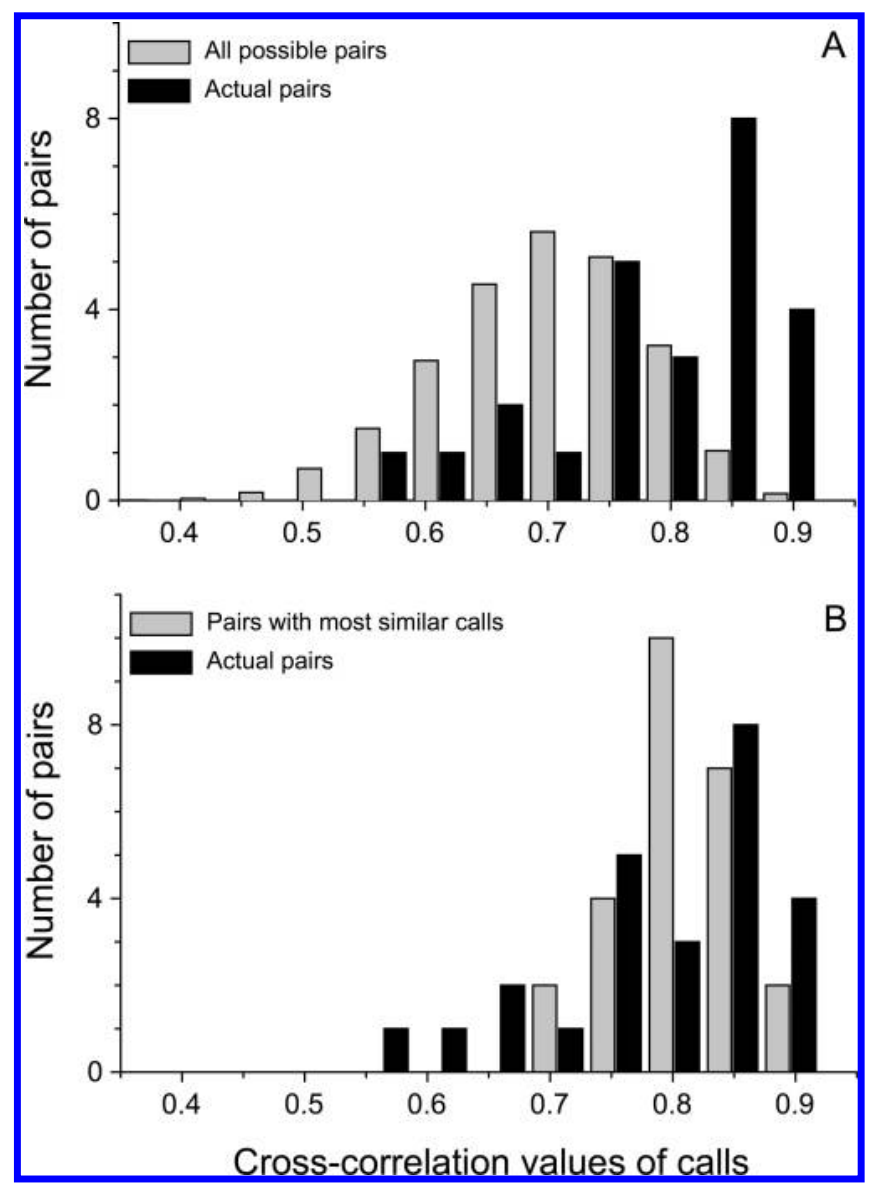

FIGURE 2. (A) The cross-correlation values for the calls of 25 actual pairs of Red Crossbills with type 9 calls in the South Hills, Idaho in 2003-2006 were greater than the values for those of 4345 possible pairs using recordings from 55 females and 79 males whose mates were unknown (scaled to total 25 pairs). (B) The distribution of crosscorrelation values for the calls of 25 actual pairs had a similar mean but larger variance than those of simulated pairs where females were paired with males having the most similar calls out of sets of 10 randomly selected males.

gave a type 2 call in 2003 and successfully fledged young while paired to a type 9 male (80887 in Fig. 4). They remained paired, and in 2004, her call changed to take on the structure of a type 9 call similar to her mate's (Fig. 4). A second case involves male cb169 who was observed paired with two different females in two years (Fig. 5). In August 2005, he was observed paired with female 80922 (with dependent young). Her call changed from 2004 to 2005 (cross-correlation value $=0.62$ ), becoming more similar to calls produced by cb169 during 2005 (crosscorrelation values increased from 0.63 to 0.84 ; Fig. 5). In 2006, cb169 paired with female 53130. Notably, this female was recorded several times in 2006 and produced calls that differed from one another, indicating either variation in her call or a shift in call structure to match that of her mate (Fig. 5). During 2006, the similarity between calls produced by 53130 


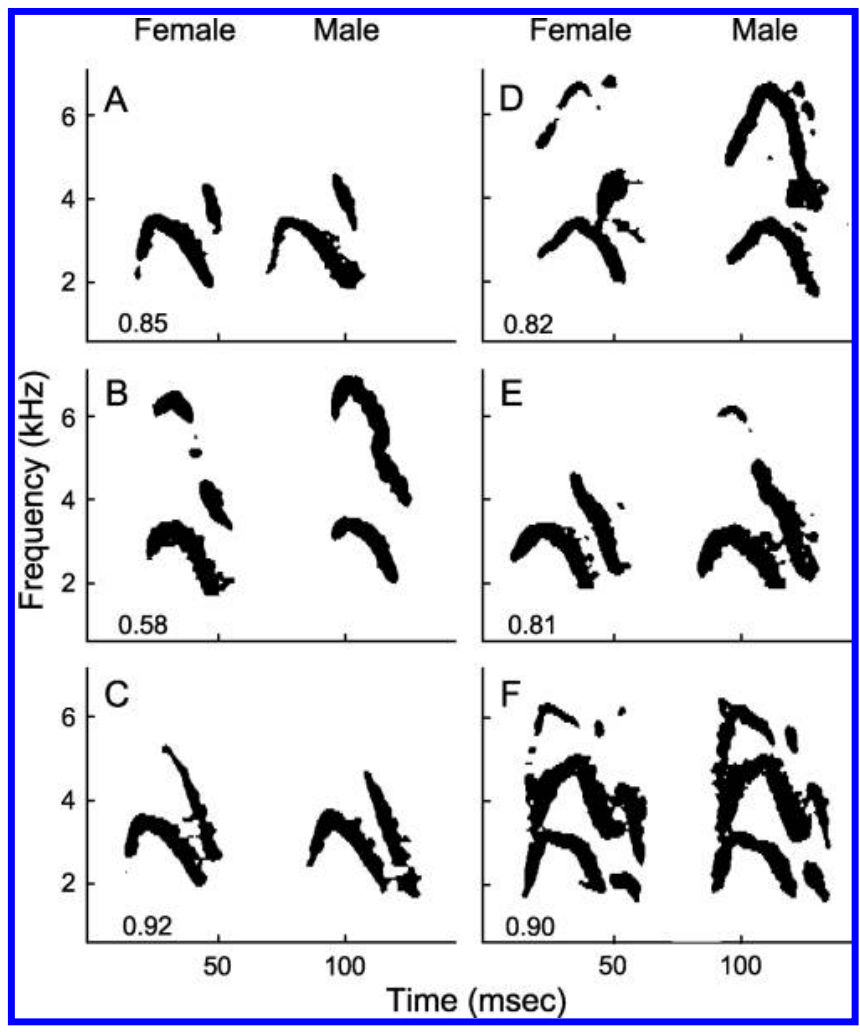

FIGURE 3. Flight calls (A-F) of mated pairs of Red Crossbills with type 9 calls in the South Hills, Idaho in 2003-2006, with the female on the left and the male on the right in each panel. The cross-correlation values of calls between mates are shown at bottom left of each panel.

and cb169 increased from 0.70 to 0.82 due to an apparent shift in call structure by 53130 and perhaps also by cb169. These results combined with additional comparisons (Fig. 2B) indicate that call matching arises because of imitation and not mate choice.

\section{CALL STABILITY}

We detected a significant decline in call similarity with increasing time interval between recordings for males $\left(F_{1,69}=9.8\right.$, $r=-0.36, P=0.003)$ but not for females $\left(F_{1,41}=1.3\right.$, $r=-0.18, P=0.26$ ). Similar results were found when we compared the similarity of calls given by individuals of the two sexes captured twice within a year to the similarity of calls given between years (males: $t_{19}=4.1, P<0.001$; females: $t_{12}=1.4, P=0.09$; Table 1 These results indicate that males tended to change their calls more over time than did females. However, our more direct evidence of call matching (Fig. 4 and 5) suggests that females tended to change their calls more than did males.

Calls of individual South Hills crossbills recorded at different times became less similar to the calls of type 2 crossbills over time $\left(t_{113}=2.9, P=0.002\right)$. However, the absolute decrease in call similarity from the initial calls made by South

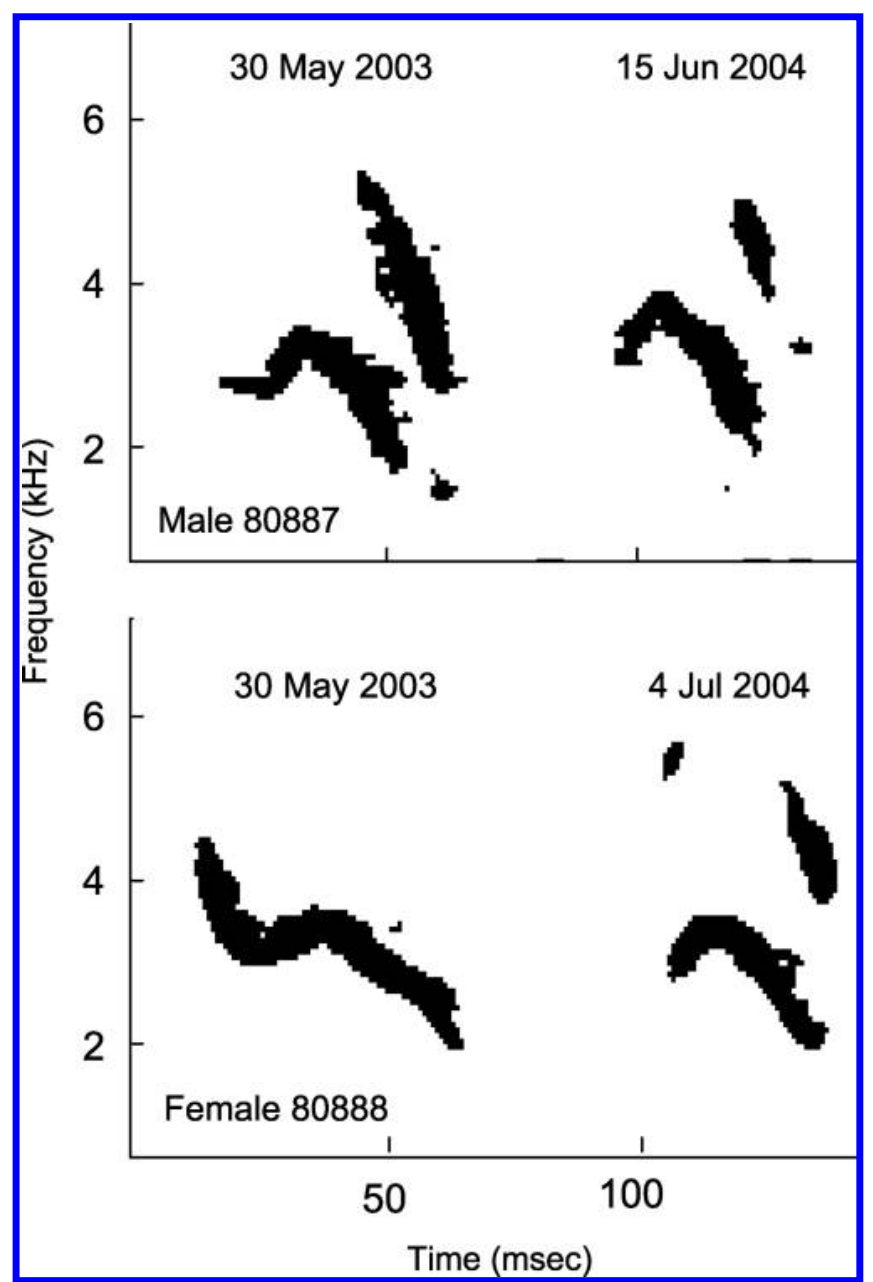

FIGURE 4. Example of a shift in call structure to match the call of a mate in Red Crossbills in the South Hills, Idaho. Male 80887 (top) paired with female 80888 (bottom) in both 2003 and 2004. Female 80888 shifted from giving a type 2 call in 2003 to giving a type 9 call that matched that of her mate in 2004. Recording dates are above each spectrogram.

Hills crossbills (cross-correlation value: $0.572 \pm 0.007$ ) to calls they made later (cross-correlation value: $0.556 \pm 0.007$ ) was not large.

\section{DISCUSSION}

Three important findings arise from this investigation of crossbill flight calls. First, in the wild, young crossbills develop calls that are similar to those of their parents within several months of hatching. Given that crossbills (Groth 1993a), like other carduelines (Mundinger 1979), learn their calls, the findings here show that calls are at least initially vertically transmitted from parents to offspring. The second finding is that wild crossbills are capable of shifting their call structures as adults and do so in order to match the calls of their mates. This supports an important role for flight calls in pair and social bonding or 


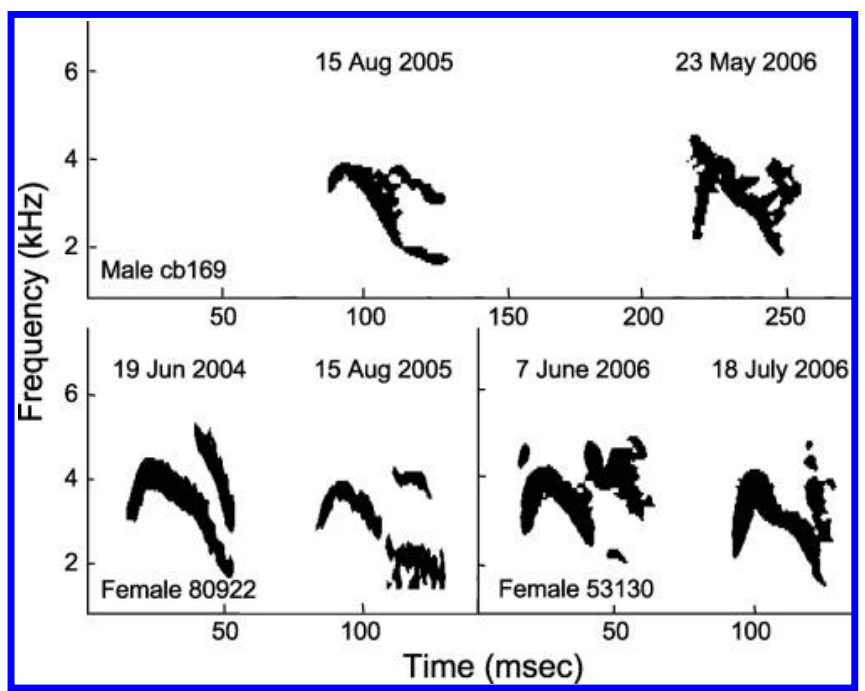

FIGURE 5. Examples of shifts in call structure to match the call of a mate in Red Crossbills with type 9 calls in the South Hills, Idaho. The call of female 80922 (bottom left) shifted from 2004 to 2005, resulting in a closer match to her mate (male cb169, top) in August 2005. Male cb169 paired with female 53130 (bottom right) in 2006, and the calls of both birds converged.

individual recognition (Mundinger 1970, 1979, Samson 1978, Hile et al. 2005). We did not find evidence that call matching resulted from mate choice as found in Budgerigars (Hile et al. 2005, Moravec et al. 2006), although male Budgerigars also shift their calls after pairing to match those of their mates (Hile et al. 2000, Moravec et al. 2006). Indeed, our results are consistent with experiments using captive Red Crossbills that indicate females prefer males within their call type whose calls differ the most from their own (L. Snowberg, University of Texas, unpubl. data). Given that crossbills learn their calls from their parents, avoiding individuals that give calls similar to their own, assuming their calls have not changed too much, provides a means to avoid inbreeding (Grant and Grant 1996). Third, the modification of calls by adults over time results in their calls becoming more distinct from the most common co-occurring call type. Such changes would be expected if distinct calls are important for assortative flocking and pairing

TABLE 1. Cross-correlation values (mean $\pm \mathrm{SD}$ ) between flight calls of individual Red Crossbills with type 9 calls in the South Hills, Idaho in 1998-2006 over different time intervals and between different individuals.

\begin{tabular}{lcr}
\hline \hline Comparison & Cross-correlation & $n$ \\
\hline Within individuals & & \\
$\quad$ Within a recording & $0.90 \pm 0.04$ & 36 \\
Recordings within one summer & $0.85 \pm 0.06$ & 33 \\
One year between recordings & $0.81 \pm 0.07$ & 48 \\
Two years between recordings & $0.80 \pm 0.09$ & 19 \\
> two years between recordings & $0.78 \pm 0.10$ & 14 \\
Between calls of different individuals & $0.71 \pm 0.04$ & 114 \\
\hline
\end{tabular}

(Smith et al. 1999, Snowberg and Benkman 2007). Below we discuss some of our results further.

\section{CALL LEARNING FROM PARENTS}

Vertical transmission of call structure from parents to offspring, specifically that which relates to call type, is critical for flight calls to act as a marker trait that signals group identity and ecological adaptation. If flight calls act as a marker trait, then they are expected to facilitate assortative mating and thereby contribute to speciation of crossbills by means of reducing gene flow between populations (Snowberg and Benkman 2007). Assortative mating along with strong selection against hybrids presumably explains the genetic structure observed among crossbill call types (Parchman et al. 2006). However, the findings here suggest that initial call learning from parents can at least occasionally be trumped by future modification of an individual's call.

\section{SHIFTS IN CALL STRUCTURE}

We have both direct and indirect evidence that paired crossbills often change their calls to match those of their mates. Nevertheless, some pairs do not match their calls. In one case, a pair did not match their calls the first year we recorded them but then did so in their second year together. Although most pairs had calls that matched, the above observation offers the possibility that some crossbills may match their calls only after they breed (perhaps successfully). However, the other examples in our study suggest that individuals may change their calls to match those of their mates during breeding attempts. The changes in calls over time across all individuals also indicate that calls often vary temporally, presumably to match those of mates. These data are consistent with, but are not as compelling as, the examples of individuals changing their calls to match those of their mates or the distribution of call similarities of observed pairs relative to pairs that would arise if females simply preferred to pair with males producing calls that were similar to their own.

Crossbills are like other previously studied carduelines in learning calls from their parents and changing them to match those of their mates. Therefore, explanations for why paired crossbills match their calls need to be general to carduelines. One hypothesis for the benefits of call matching is that calls play an important role as an individual and group recognition cue (Mundinger 1970, Falls 1982), the importance of which would be heightened in the often nomadic, opportunistically breeding carduelines (Samson 1978). Call matching may help mates to remain paired, coordinate their activities year round, and facilitate the rapid onset of breeding. Because South Hills crossbills are not nomadic like other call types of Red Crossbills (Benkman 2003, Benkman et al. 2005), we might expect a lower frequency of call matching in South Hills crossbills than in other call types due to a heightened ability to recognize individuals based on experience as residents. Interestingly, 
Smith (2005) found call matching in only approximately twothirds of the South Hills crossbill pairs, whereas data of Groth (1993b) suggest that call matching may occur at a much higher frequency in two nomadic call types.

Another consideration is that courtship feeding might play a role in vocal imitation (Mundinger 1970). Such feeding behavior is observed not only between males and females during the breeding season, but is also observed between male flock mates and may relate to social relationships (Mundinger 1970). Notably, the structure of Budgerigar contact calls is influenced by food rewards, whereby the reward reinforces the production of calls that, depending upon the experiment, either match or differ from a defined template call (Manabe and Dooling 1997). A similar mechanism in Red Crossbills would help to explain the variation observed in the calls of both males and females as well as why juveniles produce calls similar to those of their parents. However, understanding the influence of food rewards on Red Crossbill call variation requires additional investigation.

The observation of a crossbill that changed its type of call (from type 2 to type 9) between years is consistent with studies of other species of carduelines (Mundinger 1979). However, such call shifts warn against the use of call matching by investigators to categorize pairs and the subsequent inferring of the degree of assortative mating, as done by Groth (1993b). Nevertheless, we observed that only one of 79 adult crossbills recorded over more than one year changed its call to the extent that it would be recognized as another call type (this number did not change with the addition of calls from 12 crossbills that were not included in our analyses of call similarity due to poor quality recordings). The individual that shifted between types initially produced calls representative of type 2 (presumably its call type) and was one of the few banded non-type 9 crossbills that remained for more than one year in the South Hills (most non-type 9 crossbills depart from the South Hills by early autumn; Smith and Benkman 2007). Moreover, this individual changed its call only in the year after breeding successfully. No type 9 crossbill was found to change its call so that it would be recognized as another call type. If we assume that between-type shifts are limited to non-type 9 crossbills that pair with type 9 birds and remain in the South Hills for more than one year (i.e., individuals of an uncommor $\rightarrow$ call type that hybridize and remain among a common call type), then between-type call shifting in the South Hills will be rare.

Focusing only on type 2, because the smaller billed type 5 crossbill apparently cannot survive through the winter foraging on the well-defended lodgepole pine (Pinus contorta latifolia) cones in the South Hills (Smith and Benkman 2007), leaves us with five known type 2 crossbills that paired with five of the 819 breeding type 9 crossbills (Smith and Benkman 2007). If we assume that, on average, half of the $\rightarrow$ type 2 birds that hybridize remain another year and change their calls to match those of their type 9 mates, the number of hybrid pairs, including those missed because of between-type shifting, would still be less than $1 \%$ (seven or eight of 819 type 9 crossbills involved in hybrid pairs). This suggests that between-type call shifting affects our estimates of hybridization minimally. Nevertheless, the finding of call type switching is to be expected given that call types hybridize, and individuals modify their calls to match their mates.

In contrast to this one case of call switching, we found an overall trend for South Hills crossbills to shift their calls over time to become less similar to the most common other call type in the South Hills (type 2). This should make it easier for individuals to distinguish between call types, and further suggests that calls are not simply changing randomly. This increase in distinctiveness and the persistence of crossbill call types suggest that distinct calls may, in part, be maintained by ecologically based divergent selection favoring assortative flocking and pairing (Smith et al. 1999, Smith and Benkman 2007, Snowberg and Benkman 2007). Such selection is consistent with observations of high levels of assortative mating in the wild (Smith and Benkman 2007) and in aviaries (Snowberg and Benkman 2007), and has likely been critical for the diversification of different crossbill call types.

\section{ACKNOWLEDGMENTS}

We thank A. Buerkle, N. Fuzessery, D. Paulson, T. Parchman, A. Siepielski, L. Snowberg, and two anonymous reviewers for their helpful comments. L. Santisteban, J. Smith, J. Colquitt, T. Grayson, J. Hartley, K. Downham, and J. Alex enthusiastically pursued crossbills, and E. Mezquida provided help during the initiation of this study and graciously translated the abstract into Spanish. We also thank personnel in the Sawtooth National Forest Service and Idaho Fish and Game Department. This work was supported by National Science Foundation grants DEB-0212271 and DEB-0435923 to CWB and supplemental RET (DEB-0435923), REU (DEB-0422576 and DEB-0620261).

\section{LITERATURE CITED}

AdKisson, C. S. 1981. Geographic variation in vocalizations and evolution of North American Pine Grosbeaks. Condor 83:277-288.

Benkman, C. W. 1993. Adaptation to single resources and the evolution of crossbill (Loxia) diversity. Ecological Monographs 63:305-325.

Benkman, C. W. 1999. The selection mosaic and diversifying coevolution between crossbills and lodgepole pine. American Naturalist 153:S75-S91.

Benkman, C. W. 2003. Divergent selection drives the adaptive radiation of crossbills. Evolution 57:1176-1181.

Benkman, C. W., J. S. Colquitt, W. R. Gould, T. Fetz, P. C. Keenan, AND L. SANTISTEBAN. 2005. Can selection by an ectoparasite drive a population of crossbills from its adaptive peak? Evolution 59:2025-2032.

Benkman, C. W., W. C. Holimon, and J. W. Smith. 2001. The influence of a competitor on the geographic mosaic of coevolution between crossbills and lodgepole pine. Evolution 55:282-294.

Benkman, C. W., T. L. Parchman, A. Favis, And A. M. Siepielski. 2003. Reciprocal selection causes a coevolutionary arms race 
between crossbills and lodgepole pine. American Naturalis $\rightarrow$ MARLER, P. 2004. Bird calls: their potential for behavioral neurobiol162:182-194.

$\rightarrow$ Britanny-Powell E. F., R. J. Dooling, and S. M. Farabaugh. 1997. Vocal development in Budgerigars (Melopsittacus undulatus): contact calls. Journal of Comparative Psychology 111:226241.

Catchpole, C. K., and P. J. B. Slater. 1995. Bird song: biological themes and variations. Cambridge University Press, Cambridge, UK.

Charif, R. A., S. Mitchell, AND C. W. Clark. 1995. Canary 1.2 user's manual. Cornell Laboratory of Ornithology, Ithaca, NY.

$\rightarrow$ Dieckmann, U., AND M. Doebeli. 1999. On the origin of species by sympatric speciation. Nature 400:354-357.

FALLS, J. B. 1982. Individual recognition by sounds in birds, p. 237-278. In D. E. Kroodsma and E. H. Miller [EDS.], Acoustic communication in birds. Vol. 2. Academic Press, New York.

$\rightarrow$ Farabaugh, S. M., A. Linzenbold, And R. J. Dooling. 1994. Vocal plasticity in Budgerigars (Melopsittacus undulatus): evidencr for social factors in the learning of contact calls. Journal of Comparative Psychology 108:81-92.

$\rightarrow$ FARNSWORTH, A. 2005. Flight calls and their value for future ornithological studies and conservation research. Auk 122:733-746.

ogy. Annals of the New York Academy of Sciences. 1016:31-44

MARLER, P. 2005. Bird calls: a cornucopia for communication, p. 132-177. In P. Marler and H. Slabbekoorn [EDS.], Nature's music: the science of birdsong. Elsevier Academic Press, San Diego, CA.

$\rightarrow$ Moravec, M. L., G. F. Striedter, and N. T. Burley. 2006. Assortative pairing based on contact call similarity in Budgerigars, Melopsittacus undulatus. Ethology 112:1108-1116.

$\rightarrow$ Mundinger, P. C. 1970. Vocal imitation and individual recognition of finch calls. Science 168:480-482.

Mundinger, P. C. 1979. Call learning in the Carduelinae: ethological and systematic considerations. Systematic Zoology 28:270-283.

$\rightarrow$ Notтевонм, F. 1984. Birdsong as a model in which to study brain processes related to learning. Condor 86:227-236.

Parchman, T. L., and C. W. Benkman. 2002. Diversifying coevolution between crossbills and black spruce on Newfoundland. Evolution 56:1663-1672.

Parchman, T. L., C. W. Benkman, and S. C. Britch. 2006. Patterns of genetic variation in the adaptive radiation of New World crossbills (Aves: Loxia). Molecular Ecology 15:1873-1887.

RIDLEY, M. 1996. Evolution. 2nd ed. Blackwell Science, Inc., Cambridge, MA.

$\rightarrow$ Grant, B. R., AND P. R. Grant. 1996. Cultural inheritance of son€ $\rightarrow$ SAMson, F. B. 1978. Vocalizations of Cassin's Finches in northern and its role in the evolution of Darwin's finches. Evolution 50:2471-2487.

Groth, J. G. 1993a. Evolutionary differentiation in morphology, vocalizations, and allozymes among nomadic sibling species in the North American Red Crossbill (Loxia curvirostra) complex. University of California Publications in Zoology No. 127.

Utah. Condor 80:203-210.

$\rightarrow$ Sewall, K., R. Kelsey, and T. P. Hahn. 2004. Discrete variants of Evening Grosbeak flight calls. Condor 106:161-165.

SHopsin, M. [ONLINE]. 2002-2004. Michael Shopsin's software $<$ http://www.panix.com/ shopsinm/index.html> (19 December 2007).

Groth, J. G. 1993b. Call matching and positive assortative mating ir $\rightarrow$ Slabberoorn, H., And T. B. Smith. 2002. Bird song, ecology red crossbills. Auk 110:398-401.

$\rightarrow$ Hile, A. G., N. T. Burley, C. B. Coopersmith, V. S. Foster, And G. F. StRIEDTER. 2005. Effects of male vocal learning on female behavior in the Budgerigar, Melopsittacus undulatus. Ethology 111:901-923.

and speciation. Philosophical Translations of the Royal Society London Series B 357:493-503.

Smith, J. 2005. The role of coevolution in promoting ecological speciation in Red Crossbills (Loxia curvirostra complex). Ph.D. dissertation, New Mexico State University, Las Cruces, NM.

$\rightarrow$ Hile A. G., T. K. Plummer, and G. F. Striedter. 2000. Mal $\rightarrow$ Smith, J. W., and C. W. Benkman. 2007. A coevolutionary arms race vocal imitation produces call convergence during pair bonding in Budgerigars, Melopsittacus undulatus. Animal Behaviour 59:1209-1218.

$\rightarrow$ Irwin, D. E., AND T. Price. 1999. Sexual imprinting, learning and speciation. Heredity 82:347-354.

$\rightarrow$ Kleven, O., B. BJerke, AND J. T. LifJeld. 2008. Genetic monogamy $\rightarrow$ in the Common Crossbill (Loxia curvirostra). Journal of Ornithology 149 , in press.

Kroodsma, D. E., And B. E. Byers. 1991. The functions of birc $\rightarrow$ Te songs. American Zoologist 31:318-328.

$\rightarrow$ Mammen, D. L., AND S. Nowicki. 1981. Individual differences and within-flock convergence in chickadee calls. Behavioral Ecology $\rightarrow$ and Sociobiology 9:179-186.

$\rightarrow$ Manabe, K., AND R. J. Dooling. 1997. Control of vocal production in Budgerigars (Melopsittacus undulatus): selective reinforcement $\rightarrow$ call differentiation, and stimulus control. Behavioral Processes 41:117-132. causes ecological speciation in crossbills. American Naturalist 169:455-465

Smith, J. W., C. W. Benkman, and K. Coffey. 1999. The use and misuse of public information by foraging Red Crossbills. Behavioral Ecology 10:54-62.

SNOWBERG, L. K., AND C. W. BENKMAN. 2007. The role of marker traits in the assortative mating within Red Crossbills, Loxia curvirostra complex. Journal of Evolutionary Biology 20:1924-1932.

Templeton, C. N., E. Greene, And K. Davis. 2005. Allometry of alarm calls: Black-capped Chickadees encode information about predator size. Science 308:1934-1937.

WRIGHT, T. F. 1996. Regional dialects in the contact call of a parrot. Proceedings of the Royal Society of London Series B 263:867-872.

Wright, T. F., AND G. S. Wilkinson. 2001. Population genetic structure and vocal dialects in an Amazon parrot. Proceedings of the Royal Society of London Series B. 268:609-616. 